\title{
CALCINATED BENTONITE AS SUPPLEMENTARY CEMENTITIOUS MATERIALS IN CEMENT-BASED MORTAR
}

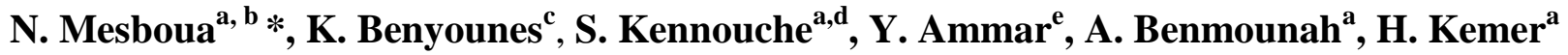 \\ ${ }^{a^{*}}$ Research Unit on Materials, Processes and Environment (UR-MPE), University M'Hamed Bougara, Boumerdes, Avenue of \\ Independence, Boumerdes, 35000, Algeria, E-mails:* mesbouhnour@hotmail.fr, nmesboua@usthb.dz, nmesbo@gmail.com \\ ${ }^{\mathrm{b}}$ Faculty of Civil Engineering, Department of Materials and structures, University Sciences and Technology Houari Boumediene \\ USTHB, El-Alia , Bab Ezzouar, Algeria \\ ${ }^{\mathrm{c}}$ Laboratory of Physical Engineering Hydrocarbons, Faculty of Hydrocarbons and Chemistry (FHC), University M'Hamed Bougara \\ Boumerdès, Avenue of Independence, Boumerdes, 35000, Algeria \\ ${ }^{\mathrm{d}}$ Department of Civil Engineering, Bouira University, Bouira 10000, Algeria \\ ${ }^{\mathrm{e}}$ Department of Civil \& Building Engineering, University of Sherbrooke, Sherbrooke, Quebec, Canada
}

Received: 05.01.2021 / Accepted: 27.01.2021/ Revised: 07.02.2021 / Available online: 31.05.2021

DOI: 10.2478/jaes-2021-0004

KEYWORDS: Bentonite, Calcinated Bentonite, Termogravimetric analysis, Differential scanning calorimetry, Strength activity index.

\begin{abstract}
:
The construction industry consumes a large quantity of cement, which therefore leads to a high $\mathrm{CO}_{2}$ emission due to the cement manufacture. The partial replacement of cement by supplementary cementations materials (SCMs) is considered as the most promising alternative to reduce the environmental impact of this industry. This investigation aims to evaluate the performance of calcinated clay (calcined bentonite at $850{ }^{\circ} \mathrm{C}$ ) used as partial replacement of cement in cement-based mortar. The evaluated performances include the physico-chemical and mechanical properties, as well as microstructural characteristics. . Various characterization tests, including laser granulometry, X-ray diffraction (XRD), and X-ray fluorescence spectrometry (XRF) have been investigated. In addition, the hardened properties of different mortar mixtures were also investigated. Mortar mix tures incorporating different calcinated clay percentages corresponding to $8,10,12$, and $14 \%$, by mass of total binder content, were proportioned. Termogravimetric analysis (TGA) and its derivative (DTG), Differential scanning calorimetry (DSC), and microstructural (Scanning electron microscopy (SEM)) analysis were carried out on samples of mortar mixtures. Furthermore, the 28-d hardened properties were assessed to assess the pozzolanic activity of the investigated mixtures. Strength activity index (SAI), DSC, and TGA analyzes are presented. The obtained results showed that all the mixtures exhibited adequate pozzolanic activity conforming to the ASTM C618 specifications.
\end{abstract}

\section{INTRODUCTION}

In recent years, various materials are used as supplementary cementations materials (SCMs) for concrete, including natural materials and industrial by-products. SCMs are used as partial substitutions of Portland cement, because of their economic, performance, and environmental benefits due to their lower imbedded energy and $\mathrm{CO}_{2}$ emissions compared to clinker manufacturing (Heede, 2012; Monteiro, 2012; Boukhelkhal, 2016). The primary benefits of SCM are the improvement of long-term mechanical performance, durability, and reduction of the carbon footprint of concrete.

Blended cement containing different SCMs, including fly ashes, slag, silica fume have been used systematically in construction industry for many years and proved good track record, hence resulting in their wide acceptance in the construction industry (1, 2, Aïtcin, Portland Cement
Association, Holcim Suisse, etc.). For example, it is reported that blended cements represented almost $75 \%$ of the production of Holcim in 2009, compared to 39\% in 1995 (Schneider, 2011), which reveals their higher use. On the other hand, in the U.S., more than $60 \%$ of ready-mixed concrete are partially replacing cement by various SCM types to concrete (Kosmatka, 2011). This increased the local demand for high quality SCMs, which hence resulted in outpacing their supply. On the other hand, in some countries, these conventional SCMs are not produced locally, particularly in developing countries where concrete traditional SCMs, such as fly ash and GGBFS, use is continuously increasing. Therefore, there is a need to explore new sources of sustainable alternative SCMs that can be exploited in enhancing performance of concrete, while meeting the sustained increasing demand (Penson, 2019.

\footnotetext{
* Corresponding author: Noureddine Mesboua, Research Unit on Materials, Processes and Environment (UR-MPE), University M'Hamed Bougara, Boumerdes, Avenue of Independence, Boumerdes, 35000, Algeria / Faculty of Civil Engineering, Department of Materials and structures, University of Sciences and Technology Houari Boumediene USTHB, BP.32 El-Alia, Bab Ezzouar, Algeria, E-mails: mesbouhnour@hotmail.fr, nmesboua@usthb.dz,nmesbo@gmail.com, Tél.: +213674370 350.
} 
Although the widespread availability of bentonite, its use in concrete was limited as thickener agent, but not as SCMs. Indeed, due to its rheological functionality, bentonite has been mainly used as thixotropic materials. On the other hand, its limited use as SCMs in concrete can be due to its poor pozzolanic reactivity compared to conventional SCM, such as métakaolin (Rackel, 2011). It is well established that clays with kaolinite contents greater than $45 \%$ have the best pozzolanic reactivity. What is the importance of phase analysis? Oxide analysis for characterizing calcinated bentonite for use as SCMs? Describe the factor affecting reactivity? The particlesize distribution and specific surface area influence reaction rate. This is dependent on the purity of kaolin.

Significant challenges for using bentonite as SCMs are to identify the impact performance and identify ways to enhance its reactivity. While bentonite contains an appropriate amount of oxides $\left(\mathrm{SiO}_{2}+\mathrm{Al}_{2} \mathrm{O}_{3}+\mathrm{Fe}_{2} \mathrm{O}_{3}\right)$, hence can be classified as pozzolans (Pelisser et.al, 2018), its structure is too stable to be soluble and reactive. The approach consists in finding the appropriate calcination temperature to disturb the crystalline structure. Bentonite is an aluminosilicate mineral available in volumes exceeding several million tones. It is obtained by thermal transformation of kaolinite, which is mined in many parts of the world. Calcination of kaolinite at temperature between $550-900^{\circ} \mathrm{C}$ to dehydrate and amorphized its crystalline structure (Taher, 2003). This can therefore result in sufficiently reactive aluminosilicate materials. It should be noted that the calcination temperature should be carefully controlled to avoid formation of inert phases such as mullite. In order to support the increasing use of clay-derived SCMs and enhance the environmental and performance of cement-based materials, it is important to develop a good understanding of the chemical structures and reactivities of these materials (Penson, 2019).

In construction, reducing $\mathrm{CO}_{2}$ emission is projected as an objective, for these, one proposed solution is using pozzolanic additions to replace cement such as slag, silica fume and pozzolans because they enhance the rheological, strength, durability and transfer properties (Sharma and Khan, 2018).

These improvements are explained and attributed to the pozzolanic activity of these materials because if Portlandite is present, it leads to additional calcium silicate hydrates (C-S-H). The incorporating of calcined bentonite was studied by many author's, and their effect on the fresh and hardened properties of pastes, mortar, and concrete has been explored; for instance (Memon et.al., 2011) investigated the use of raw bentonite as a partial replacement for cement in concrete and found that the workability, fresh density, and water absorption of concrete decreased as the amount of bentonite increased, but bentonites increased the strength at 56 days. Comparable results are described elsewhere (Rajczyk, J. and B. Langier, 2012; Mirza et al., 2009; Ahmad et al., 2011) studies of the Effect of Pakistani bentonite in mortars and concrete as low cost construction material. In the study of self-compacting concrete (Khushnood et al., 2014) investigated the use of Wheat Straw Ash and Bentonite in Self-Compacting Cementations System.

Taylor-Lange et al. (2015) reported the positive effect of calcined bentonite as a substitute for cement when it is blended with calcined kaolinite. In the microstructure proprieties $\mathrm{CH}$ et.al, 2019; Man et.al, 2019) studied the engineering proprieties, microstructure and permeability of cement mortar.
Zine El-Abidine et.al. (2020) studies the effect of using calcined bentonite as partial replacement of Ordinary Portland Cement on the sustainability of self-compacting concrete. The cement in SCC mixes has been replaced with two different types of $\mathrm{CB}$ at $0,5,10,15,20,25$ and $30 \%$ by weight. Slump flow, V-funnel flow time, L-box test and sieve stability tests are performed to evaluate the fresh properties of SCC mixtures. Various tests are used to assess the performance of SCC mixtures in hardened states, such as compressive strength, porosity accessible to water, chloride-ions penetration and gas permeability. The results showed that the use of $\mathrm{CB}$ in SCC mixes reduced the fresh properties of SCC and the slump flows, flow times, and segregation tests are good enough for SCC production. At a hardened state, SCC with $10-15 \%$ of $\mathrm{CB}$ had a higher compressive strength up to 90 days, as well as improved porosity, chloride-ions penetration and gas permeability properties. These results indicate that a $\mathrm{CB}$ solution will reduce $\mathrm{CO}_{2}$ emissions and make durable and eco-friendly SCC at a low cost.

\section{MATERIALS AND METHODS}

\subsection{Materials}

The investigated mixtures were proportioned using an ordinary Portland cement (CEM-I $42.5 \mathrm{~N}$ ) complying with the NF EN 196-1 (2006) and ASTM C150 M (2011) specifications. The CEM-I $52.5 \mathrm{~N}$ cement has a specific gravity of 3.13, a Blaine specific surface area of $3630 \mathrm{~cm}^{2} / \mathrm{g}, \mathrm{a} \mathrm{C}_{3} \mathrm{~A}$ content of $6.60 \%$, and initial and final setting times of 117 and $212 \mathrm{~min}$, respectively. On the other hand, analumina bentonite type was used. The bentonite samples were first crushed and passed through a 60 um-sieve.Then, its characteristics were determined according to the NF EN 197-1 (2012) specifications, which specify that the reactive $\mathrm{SiO}_{2}$ content shall be not less than $25 \%$, by mass. Accordingly, the used bentonite satisfies this requirement. The calcination process was carried out by first drying the bentonite in an oven at a constant temperature of $105^{\circ} \mathrm{C}$ for 24 hours, and then the dried bentonite obtained was sieved to determine the granular distribution. The bentonite was then calcinated at a constant temperature of $850^{\circ} \mathrm{C}$ for $6 \mathrm{~h}$ (Fig 1). An optimum for bentonite clay calcinations recognized in literature is between 650 and $930^{\circ} \mathrm{C}$ (Taylor-Lange et.al, 2015).The calcined bentonite was kept away from air and humidity till the characterization tests. The particle-size distributions of the used materials are shown in Figure 2. The properties of sand used to proportion the investigated mixtures comply with the NF EN 933-1 (2012) and NF P15-403 (1963) specifications. The sand equivalent test visual was 70.91 and Methyl blue value was 0,7 .

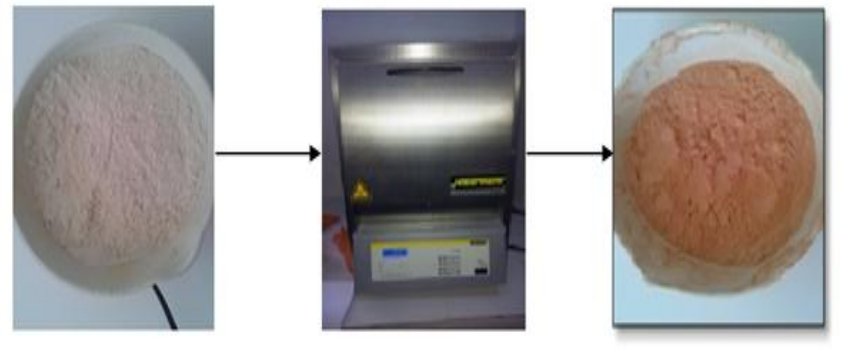

Figure 1. Preparation of calcined bentonite 


\subsection{X-ray fluorescence}

The X-ray fluorescence (XRF) analysis is used to quantitatively determine the oxides content according to the NF P 15-467 (1985) specifications. The chemical, mineralogical composition and physical properties of bentonite and calcined bentonite, as well as Portland cement are summarized in Tables 1 and 2.

\begin{tabular}{|c|c|c|c|c|c|}
\hline \multirow{2}{*}{\multicolumn{2}{|c|}{ Oxide/ Material }} & \multicolumn{3}{|c|}{ Chemical composition (\%) } & \multirow{2}{*}{$\frac{\text { ASTM C618 }}{\text { Class N requirements (\%) }}$} \\
\hline & & CEM I & Bentonite & Calcinated bentonite & \\
\hline Silicon dioxide & $\mathrm{SiO}_{2}$ & 21.29 & 60.53 & 64,23 & \\
\hline Aluminum oxide & $\mathrm{Al}_{2} \mathrm{O}_{3}$ & 4.72 & 17.41 & 19,39 & \\
\hline Ferric oxide & $\mathrm{Fe}_{2} \mathrm{O}_{3}$ & 3.49 & 2.06 & 5,19 & \\
\hline Magnesium oxide & $\mathrm{MgO}$ & 0.44 & 7.63 & 1.81 & 5 max. \\
\hline Calcium oxide & $\mathrm{CaO}$ & 63.10 & 0.86 & 3.79 & \\
\hline Sodium oxide & $\mathrm{Na}_{2} \mathrm{O}$ & 0.10 & 9.62 & 1.49 & \\
\hline Potassium oxide & $\mathrm{K}_{2} \mathrm{O}$ & 0.50 & 0.23 & 1.52 & \\
\hline Phosphor uspent oxide & $\mathrm{P}_{2} \mathrm{O}_{5}$ & 1.45 & 0.03 & 0.02 & \\
\hline Sulfur trioxide & $\mathrm{SO}_{3}$ & - & 0.09 & 0.08 & \\
\hline Titanium oxide & $\mathrm{TiO}_{2}$ & 1.92 & 0.10 & 0.09 & \\
\hline Loss on Ignition & LOI & - & 0.05 & 1.12 & 10 max. \\
\hline & $\mathrm{SiO}_{2}+\mathrm{Al}_{2} \mathrm{O}_{3}+\mathrm{Fe}_{2} \mathrm{O}_{3}$ & - & 79 & 88.81 & $70 \mathrm{~min}$. \\
\hline
\end{tabular}

Table 1. Chemical composition of bentonite, calcined bentonite and CEM I cement

\begin{tabular}{|c|c|c|c|c|c|c|}
\hline Phase & \multicolumn{3}{|c|}{ Minerals } & Content $(\%)$ & \multicolumn{2}{|c|}{$\begin{array}{c}\text { Physical and mechanical properties of } \\
\text { cement (CEM I) }\end{array}$} \\
\hline \multirow[t]{5}{*}{ Clinker } & Tricalcium silicate & $\mathrm{Ca}_{3} \mathrm{SiO}_{5}$ & $\mathrm{C}_{3} \mathrm{~S}$ & 55.0 & Specific gravity & 3.13 \\
\hline & Dicalcium silicate & $\mathrm{Ca}_{3} \mathrm{SiO}_{4}$ & $\mathrm{C}_{2} \mathrm{~S}$ & 19.4 & Initial setting time $(\mathrm{min})$ & 117 \\
\hline & tricalcium Aluminate & $\mathrm{Ca}_{3} \mathrm{Al}_{2} \mathrm{O}_{6}$ & $\mathrm{C}_{3} \mathrm{~A}$ & 06.6 & Final setting time (min) & 212 \\
\hline & \multirow{2}{*}{ Tetracalciumaluminoferrite } & \multirow{2}{*}{$\mathrm{Ca}_{4} \mathrm{Al}_{2} \mathrm{Fe}_{2} \mathrm{O}_{10}$} & \multirow{2}{*}{$\mathrm{C}_{4} \mathrm{AF}$} & \multirow{2}{*}{13.0} & Blain fineness $\left(\mathrm{cm}^{2} / \mathrm{g}\right)$ & 3630 \\
\hline & & & & & Normal consistency $(\%)$ & 25.5 \\
\hline \multirow{6}{*}{$\begin{array}{l}\text { Setting } \\
\text { regulator }\end{array}$} & \multirow{6}{*}{-} & \multirow{6}{*}{-} & \multirow{6}{*}{ Gypse } & \multirow{6}{*}{05.0} & Expansion $(\mathrm{mm})$ & $<2.5$ \\
\hline & & & & & Drying shrinkage at 28 days $(\mu \mathrm{m} / \mathrm{m}$ & $<1000$ \\
\hline & & & & & 2-days & 15.8 \\
\hline & & & & & 7- days & 20.9 \\
\hline & & & & & 28-days & 45.6 \\
\hline & & & & & $\mathrm{C}_{3} \mathrm{~A}(\%)$ & 6.60 \\
\hline
\end{tabular}

Table 2. Mineralogical composition, physical and mechanical properties of CEM I

\subsection{Physical characteristics of the bentonite}

\subsubsection{Particle size analysis by laser diffraction}

The measurement laser diffraction particle size distributions of the particles by measuring the angular variation of the intensity of scattered light when a laser beam passes through a sample of dispersed particles. Large particles scatter light at small angles relative to the laser beam and smaller particles scatter light at angles greater. The data for the scattered intensity depending on the angle is analyzed to calculate the size of particles that created the diffraction image. The particle size is the diameter of the equivalent sphere having the same volume as the particle. The results of the particle size analysis by laser diffraction of cement, bentonite and calcined bentonite are presented in Figure 2.

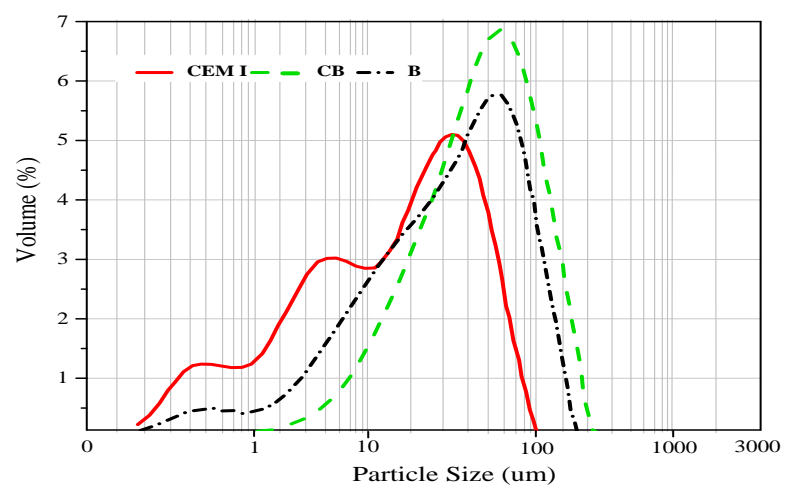

Figure 2. Particle size analysis of materials

Introduction of bentonite as cement replacement, and higher the bentonite contents lower is the density. This is due to the fact that the density being a function of specific gravity. Regarding the interval D [V, 0.5] $(\mu \mathrm{m})$, the cement is 12,367 , bentonite is 9,806 and calcined bentonite is 9,695. 
2.3.2. X-ray diffraction of cement, both bentonite and calcinated bentonite

$\mathrm{X}$-ray powder diffraction is a rapid analytical technique primarily used for phase identification of a crystalline material and can provide information on unit cell dimensions. The analyzed material is finely ground, homogenized, and average bulk composition is determined (Hluchy, 1999; Brady et al., 1995). In X-ray diffraction spectra, the strongest lines correspond to reflections perpendicular to the planes of sheets and thus are representative of d001. To better define the mineralogical composition of materials, we need to determine the nature and quantity of the various impurities contained therein. Their quantification is difficult. Some of them are abundant while others are barely detectable by Xray. The diffractogram was obtained from the disoriented samples (placed directly in powder form into a conventional sample holder). The resulting spectrum of the crude samples gives us information on impurities and other constituents present. To better define the mineralogical composition of clay materials, we need to determine the nature and quantity of the various impurities contained therein. Their quantification is difficult. Some of them are plentiful, while others are barely detectable X-ray (Hollecher and Kurt, 2012; Perkins et.al., 2021). The resulting spectrum of the crude samples gives us information on impurities and other constituents present. The XRD results of cement, bentonite and calcined bentonite are shown in Figures 3, 4 and 5.

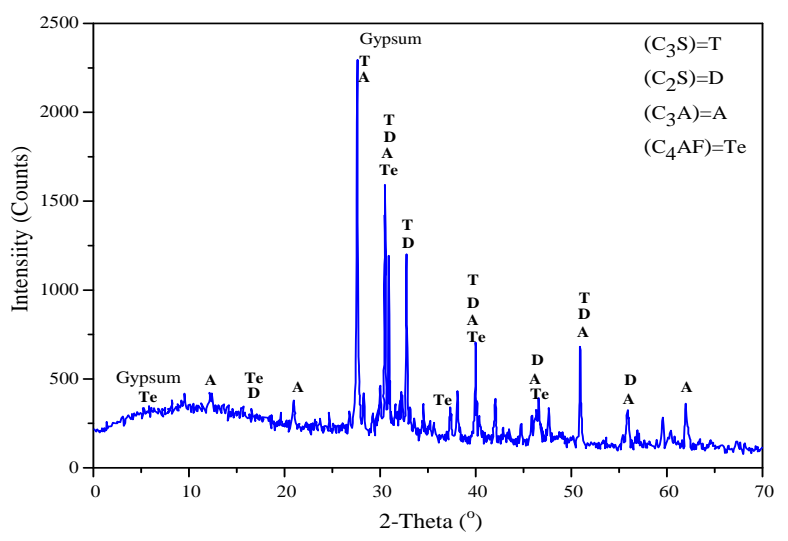

Figure 3. XRD pattern of cement

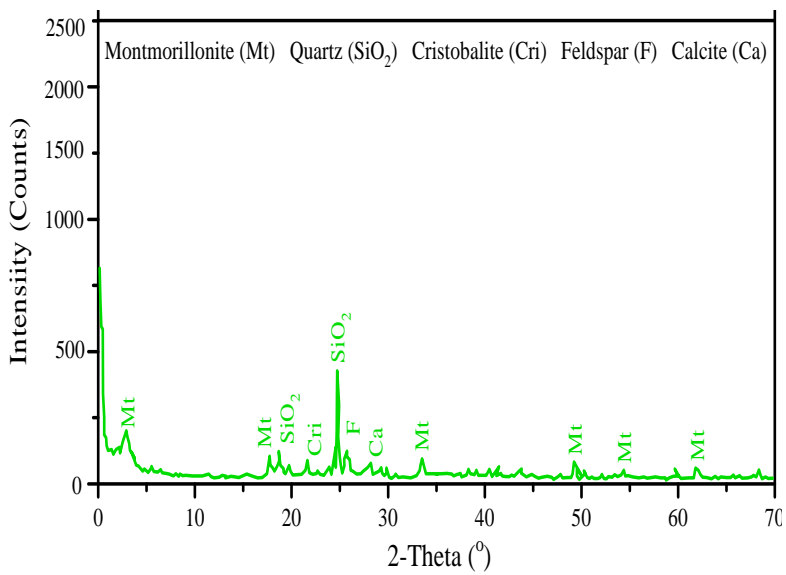

Figure 4. XRD pattern of bentonite before calcination

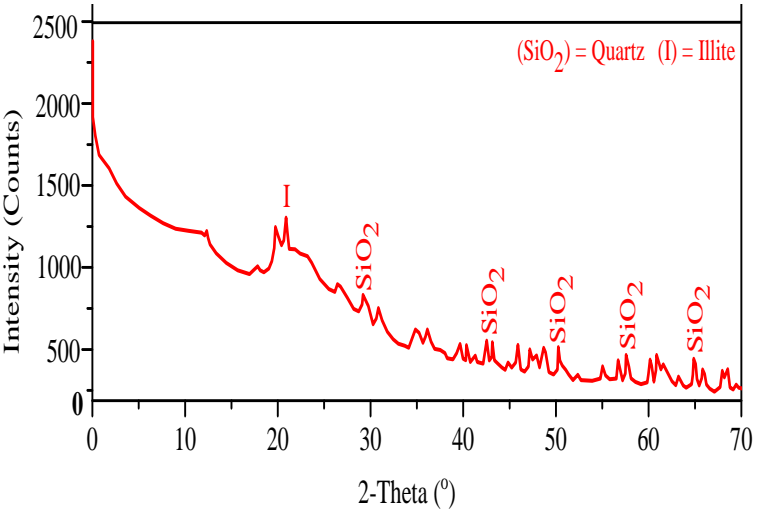

Figure 5. XRD pattern of bentonite after calcinations $850^{\circ} \mathrm{C}$

Fig. 3 shows the X-ray diffraction pattern which allows identifying various mineralogical phases contained in the Portland cement. Several peaks appear on the diffractogram of CEM I at different intensities, which can be attributed presumably to $\mathrm{C}_{3} \mathrm{~S}$ alite $\left(2 . \theta=30^{\circ}\right.$ and $\left.32^{\circ}\right), \mathrm{C}_{2} \mathrm{~S}$ and $\mathrm{C}_{4} \mathrm{AF}$ $\left(2 . \theta=14^{\circ}, 22^{\circ}, 32^{\circ}\right.$ and $\left.40^{\circ}\right)$ and celite $\mathrm{C}_{3} \mathrm{~A}$ (main line at $2 . \theta$ $=15^{\circ}$ and $32^{\circ}$ ).

There is a main reflection and this corresponds to the mineral of montmorillonite. Some peaks have been identified as impurities. The X-ray diffraction pattern of bentonite (Fig. 4) shows the major phase of montmorillonite whose the main peak is at $2 \theta=20^{\circ}$ and $35^{\circ}$. The presence of Quartz at $2 \theta=$ $21^{\circ}$ and $27^{\circ}$ is noted. A peak of $2 \theta=30^{\circ}$ appears on the sample with a different intensity, which can be attributed, presumably, to calcite. The reflection at $2 \theta=28^{\circ}$ on the Maghnia clay proves the presence of sodium feldspar. Figure 5 shows the X-ray diffraction pattern for identifying the different minerals contained in calcined bentonite. The presence of quartz at $\left(2 \theta=29^{\circ}, 46^{\circ}, 50^{\circ}, 58^{\circ}, 61^{\circ}\right)$ and illite $\left(2 \theta=20^{\circ}, 22^{\circ}\right)$.

2.3.3. Thermogravimetric analysis (TGA, DTG) and Differential scanning calorimetry (DSC)

Thermogravimetric analysis (TGA) and its derivative (DTG) allow the measurement of the mass variation of a sample placed in an oven at a rate of rise in temperature. Mass loss is followed by continuous measurement using a scale. The results are generally represented on mass loss curves as a function of the temperature and the derivative of the loss of mass as a function of temperature, which makes it possible to clearly discern the temperatures in which the thermal phenomena occur. This thermal technique makes it possible to measure the differences in heat exchange between a sample to be analyzed and a reference, which makes it possible to show certain reactions or phase changes producing without mass variation (and therefore undetectable by TGA). in particular the transformation of $\alpha$ quartz into $\beta$ quartz at $573^{\circ} \mathrm{C}$, or the formation of mullite precursors when the clay is heated to above $950^{\circ} \mathrm{C}$ (NF P 18-582, 2017). The TGA and DSC curves were drawn for bentonite and calcined bentonite powders as shown in Figure 6 . 


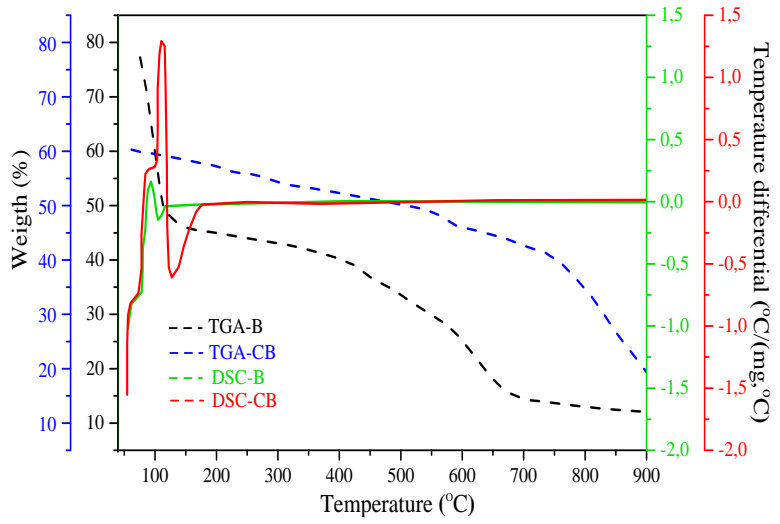

Figure 6. TGA-DSC curves of bentonite before and after calcination

\subsection{Test methods and mixture proportioning}

Test methods and mixture proportioAll the conducted tests were performed according to the ASTM and European standards. The mortar mixtures were proportioned using constant water-to-cement (W/C) ratio of 0.50 and sand-tocement $(\mathrm{S} / \mathrm{C})$ of 3 , by weight. On the other hand, various calcined bentonite at different replacement percentages of 8 , 10,12 , and $14 \%$, by weight of cement. Furthermore, a mortar mixture incorporating $14 \%$, by weight of cement, of metakaolin was investigated for comparison purposes. The mixture proportioning of the investigated mixtures are summarized in Table 3 . The mixtures were mixed according to the NF EN 196-1 (2006) specifications. The mortar mixtures were using in a relab mixer. For each of the investigated mixtures, several $40 \times 40 \times 160 \mathrm{~mm} 3$ prisms were sampled and covered to prevent water evaporation and stored at room temperature of $23 \pm 2{ }^{\circ} \mathrm{C}$ for the first 24 hours of age. The specimens were then demolded and cured in water at $23 \pm 2 \mathrm{C}$ till the age of testing (28 days). The reported average values were determined on three different samples. For each mixture, three were prepared.

\begin{tabular}{|c|c|c|c|c|c|c|c|}
\hline Mix & \multicolumn{2}{|c|}{ C B } & \multicolumn{2}{|c|}{ M } & $\mathrm{C}$ & $S(g)$ & $\begin{array}{c}\mathrm{W} \\
(\mathrm{ml})\end{array}$ \\
\hline & $(\%)$ & $(\mathrm{g})$ & $(\%)$ & (g) & (g) & \multirow{7}{*}{$\begin{array}{l}\stackrel{n}{n} \\
n\end{array}$} & \multirow{7}{*}{ 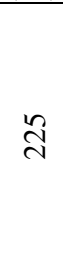 } \\
\hline Control & 0 & 0 & 0 & 0 & 450 & & \\
\hline CB 8 & 8 & 36 & - & - & 414 & & \\
\hline CB 10 & 10 & 45 & - & - & 405 & & \\
\hline CB 12 & 12 & 54 & - & - & 396 & & \\
\hline CB 14 & 14 & 63 & - & - & 387 & & \\
\hline MK 14 & - & - & 8 & 36 & 414 & & \\
\hline
\end{tabular}

Table 3. Mixture proportion of the investigated mixtures

\section{TEST RESULTS AND DISCUSSION}

\subsection{Effect of calcination on the chemical composition of bentonite}

For calcined clays, it is a principal challenge to understand the atomic-scale changes in the structure of the clay undergoing thermal treatment. In addition, information on which structural phases correspond to maximum reactivity/dissolution and at what point the amorphous clay is rendered UN reactive are questions of primary importance. The structurally pure montmorillonite has been characterized and its pozzolanic reactivity as a function of its thermal decomposition sequence has been reported. The maximum reactivity for this montmorillonite corresponded to an amorphous structure that is completely dehydroxylated and free from condensed phases which will crystallize out at high heating temperatures $\left(850^{\circ} \mathrm{C}\right)$. It is of interest to determine if similar mechanisms govern the behavior of interstratified clays (Garg and Skibsted, 2014).

\subsection{Effect of calcined bentonite on fresh properties of mortar mixtures}

This test consists of measuring the slump diameter of mortar on a horizontal plate depending on the variation of various parameters such as time, amount of water or the composition of the mortar. After the end of mixing, the mortar is introduced immediately into the mini cone (for mortar). A few seconds later, the mini cone is lifted and, after stabilization, the measurement of the spread (average of two perpendicular measurements) is performed. The main advantages of this test are the ease of implementation and low material requirements (the volume of the mini cone is less than $40 \mathrm{ml}$, the upper diameter is $2 \mathrm{~cm}$, the lower diameter is $4 \mathrm{~cm}$ and the height is $6 \mathrm{~cm}$ ). The mini slump values for the mixtures made with different percentages of calcined bentonite $(8,10,12$ and 14\%) and cement CEM I are illustrated in Figure 7.

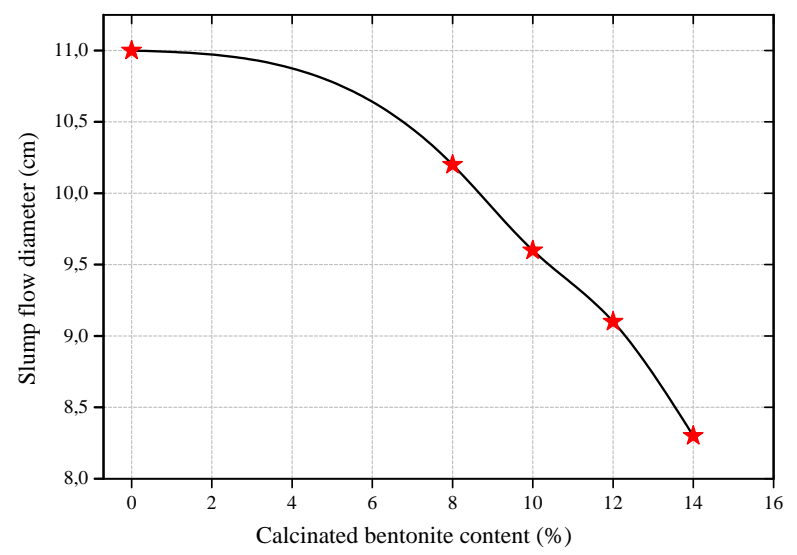

Figure 7. Slump values of different mixes.

The slump values, a measure of fresh properties of mortar (fluidity) decreased as the amount of calcined bentonite in the mix increased. The reduction in slump value is due to the small particle size and relatively higher surface area of bentonite particles. It can therefore be concluded that for the same water binder ratio, mortar made calcined bentonite is less workable than the control. Also, the results reported herein are in agreement with the available literature on bentonite (Mirza et al., 2009; Abali et.al., 2006; Sonebi et al., 2012; Noureddine et.al., 2018].

\subsection{Effect of calcined bentonite on fresh properties of mortar mixtures}

Effect of calcined bentonite on strength development of mortar mixtures. After calcination at the selected temperature $\left(850^{\circ} \mathrm{C}\right)$, the calcined bentonite samples were used as SCMs and tested in mortars, to determine compressive strength and 
pozzolanic reactivity, respectively. The compressive strength of the mortar was determined at 7, 28 and 56 days, and the test results as a function of age are presented in Fig 8, as expected the compressive strength increased with age. The rate of increase depended upon the level of calcined bentonite replacement and age.

\begin{tabular}{|l|c|c|c|c|c|c|c|}
\hline \multirow{2}{*}{ Mix } & \multirow{2}{*}{$\begin{array}{c}\text { Calcined } \\
\text { bentonite (\%) }\end{array}$} & \multicolumn{4}{|c|}{ Compressive strength (MPa) } & \multicolumn{2}{c|}{$\begin{array}{c}\text { Strength activity index } \\
(\%)\end{array}$} \\
\cline { 3 - 8 } & & 2-days & 7-days & 28-days & 56-days & 7-days & 28-days \\
\hline Control & 0 & 18.5 & 40.2 & 49.30 & 55 & 100.00 & 100.00 \\
\hline CB 8 & 8 & 22 & 40.4 & 50 & 55.30 & 100.49 & 101.41 \\
\hline CB 10 & 10 & 22.8 & 40.8 & 51.20 & 56.80 & 101.49 & 103.85 \\
\hline CB 12 & 12 & 23.5 & 41.7 & 53 & 58 & 103.73 & 107.50 \\
\hline CB 14 & 14 & 24.5 & 42.1 & 53.50 & 58.70 & 104.72 & 108.51 \\
\hline MK 14 & 14 & 24.8 & 42.6 & 53.70 & 59 & 105.97 & 108.92 \\
\hline
\end{tabular}

Table 4. The compressive strength of the cement mortar and strength activity index

The results show that the compressive strength increases with the increasing calcined bentonite content at all ages. As seen in Table 4, it is observed that the compressive strength of control mortar (CB 0) achieved a compressive strength of 18.5 $\mathrm{MPa}$ at the age of two days, $40.2 \mathrm{MPa}$ at the age of seven days, $49.3 \mathrm{MPa}$ at the age of 28 days, and $55 \mathrm{MPa}$ at the age of 56 days. The compressive strength of the mortars (CB8, CB10, CB12 and CB14) containing calcined bentonite ranged from 22.00 MPa to $24.5 \mathrm{MPa}$ at the age of two days, 40.4 $\mathrm{MPa}$ to $42.1 \mathrm{MPa}$ at the age of seven days, $50 \mathrm{MPa}$ to $53.5 \mathrm{MPa}$ at the age of 28 days, and $55.3 \mathrm{MPa}$ to $58.7 \mathrm{MPa}$ at the age of 56 days. When these values compare with the control mortar, these results of compressive strength are explained by Strength activity index.

The strength activity index (SAI) can be assessed in order to evaluate the pozzolanic activity of SCMs. The SAI was evaluated as the ratio of the compressive strength of cement mortar with calcined bentonite to the strength of cement mortar without calcined bentonite at the same age, as the percentage.

$$
\mathrm{SAI}=(\mathrm{A} / \mathrm{B}) \times 100 \%(\text { ASTM C618 a (2008) Standard })
$$
Where:

$$
\begin{aligned}
\mathrm{A}= & \text { average compressive strength of the cement } \\
& \text { mortar cubes containing calcined bentonite, and } \\
\mathrm{B}= & \text { average compressive strength of cement mortar } \\
& \text { cubes without calcined bentonite. }
\end{aligned}
$$

When the value of SAI exceeds $75 \%$ at 28 -days, the pozzolan is considered as active according to ASTM Standard C618. SAI results presented in Table 2 show that all the specimens have a SAI from 101.41 to $108.51 \%$ at 28 days depending the amount of calcined bentonite in the cement mortar (conformed to the ASTM Standard C618 specifications). The values of SAI above $75 \%$ will be ascribed to the pozzolanic reaction of active phases (silica and alumina) with the calcium hydroxide released during the cement hydration. At the age of 28 days, the mixes containing calcined bentonite showed the $1.41,3.85,7.50$, and $8.51 \%$ increase compared to control mortar, also decrease the $0.41 \%$ compared to mixes containing metakaolin at $14 \%$. These results are in good agreement with the literature (Mirza et al., 2009; Ahmad et al., 2011; Abali et.al., 2006).

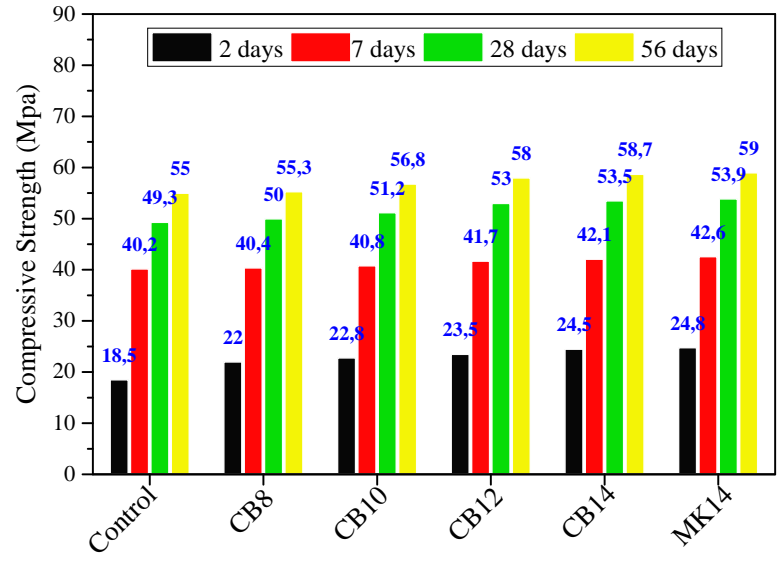

Figure 8. Compressive strength of the cement mortars versus time

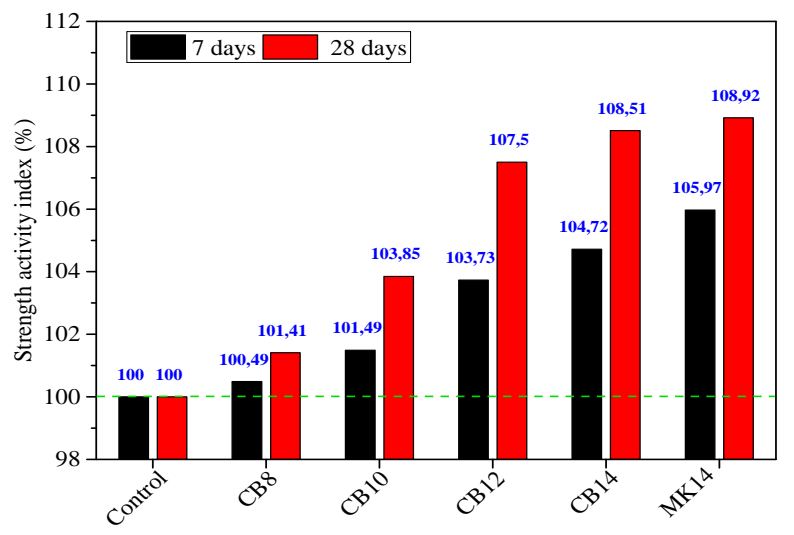

Figure 9. Variation of strength activity index-to-quantity of calcinated bentonite

\subsection{Estimation of pozzolanic activity by DSC and TGA} analyzes

The evolution of the pozzolanic reaction in the pastes of cement-clay mixtures can be followed by Differential scanning calorimetry (DSC) analysis methods and thermogravimetric analysis (ATG). These analyzes aim to identify the nature of the hydrates formed in the mortar pastes (Khelifa Mohammed Rissel, 2009). The study of mixtures (cement - calcined bentonite) in pastes is a simplified approach to that of cement paste in which the main reaction is 
the fixation, by portlandite originating from the hydration of $\mathrm{C}_{3} \mathrm{~S}$ by producing $\mathrm{C}-\mathrm{S}-\mathrm{H}$. For analyzes, representative samples of a few grams are broken into small pieces using a hammer. The pieces are then ground in a grinder and passed through an 80 micron sieve. Because ettringite loses its water molecules and gradually becomes amorphous as the temperature increases, grinding is done in several stages to limit the heating of the sample. In order to determine the contents of the various components of our samples, thermogravimetric analyzes were carried out on five types of samples in mortar control and based on calcined bentonite $(0$, $8,10,12$ and 14) \%.In this technique, the sample is heated from ambient temperature to $1200^{\circ} \mathrm{C}$ at a constant speed of $10^{\circ} \mathrm{C}$ per minute; this large ramp only has the effect of an inertia effect of the mass loss compared to the temperature actually applied. The loss of mass linked to the departure of water. In the oven, the sample is placed in burrows. The paces of mass loss curves are represented by figures 10, 11, 12 and 13 for each mortar specimen.

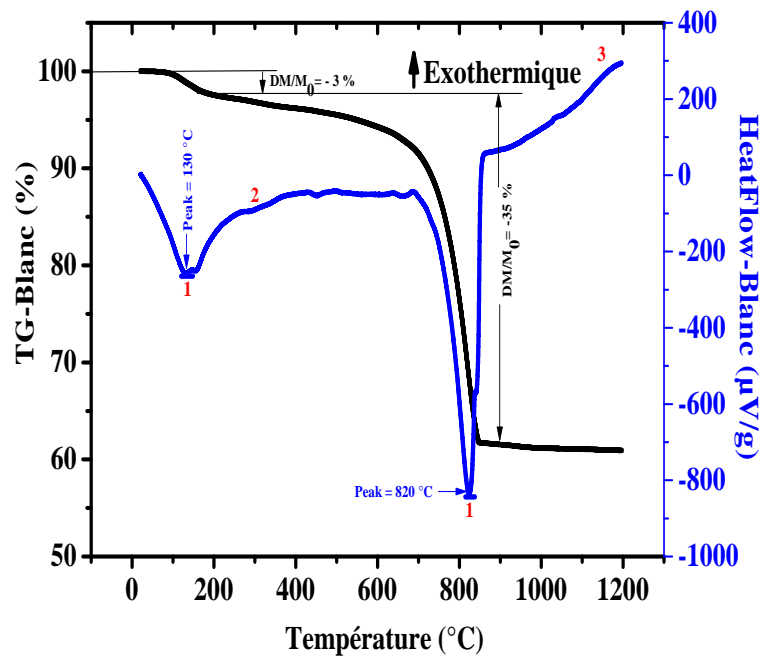

Figure 10. TGA-DSC curves of OPC

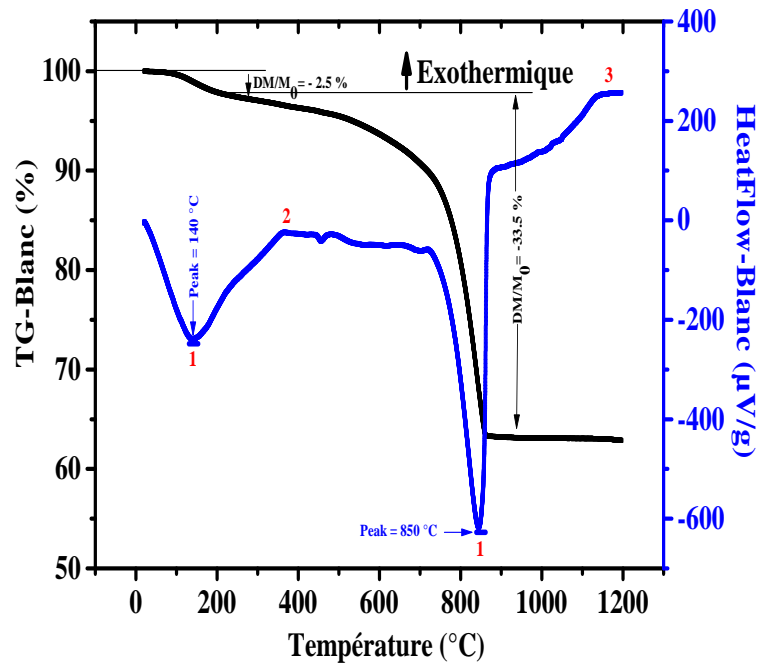

Figure 11. TGA-DSC curves of CB8 and CB10

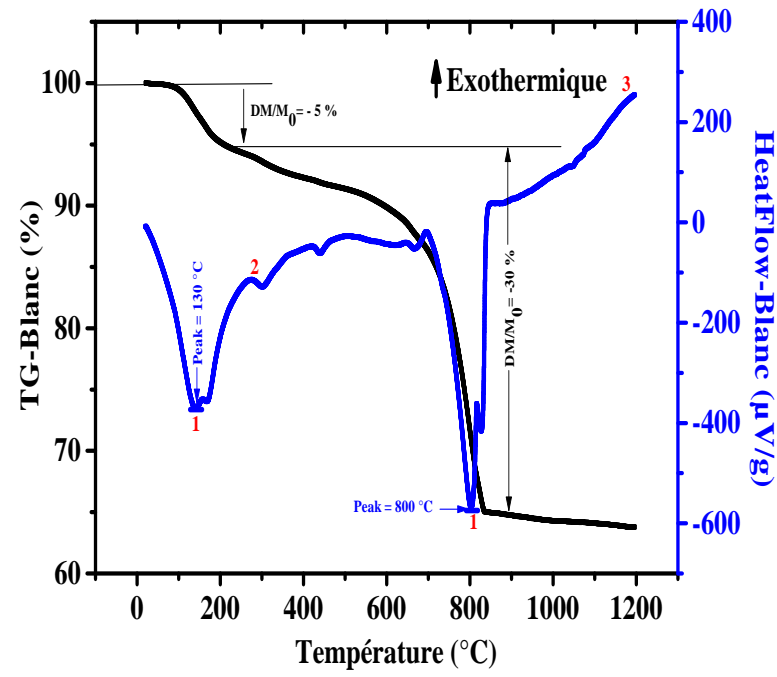

Figure 12. TGA-DSC curves of CB12

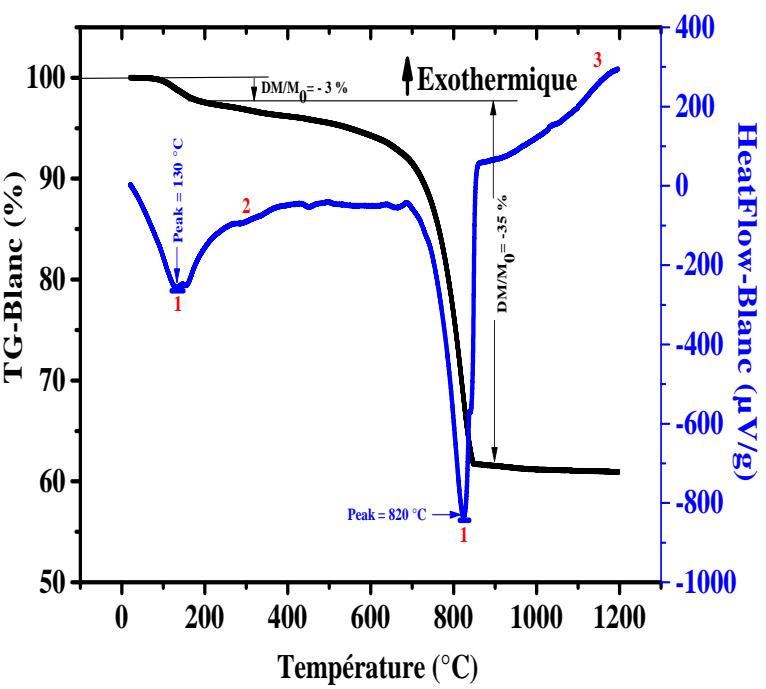

Figure 13. TGA-DSC curves of CB14and MK14

The weight loss is illustrated in figure 14 .

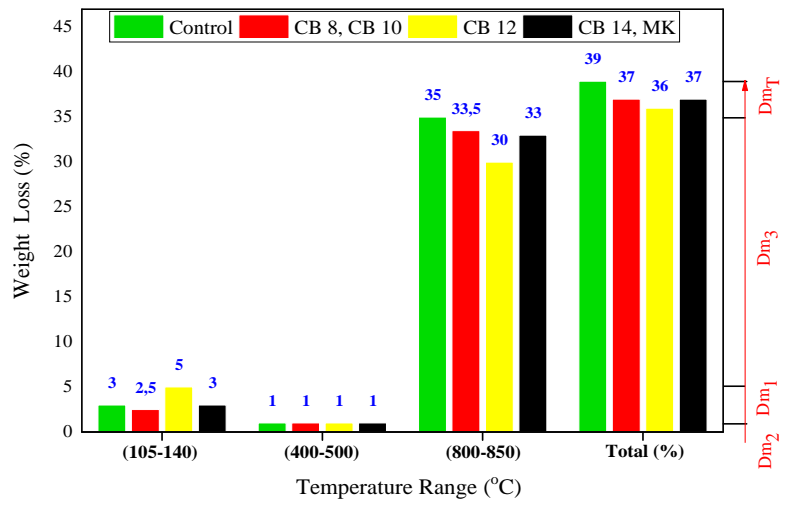

Figure 14. TGA results for OPC and Mixts

$\Delta \mathrm{m}_{1}$ : percentage corresponding to the loss of $\mathrm{H}_{2} \mathrm{O}, \mathrm{C}-\mathrm{S}-\mathrm{H}$ and possibly ettringite (around 105 to $140^{\circ} \mathrm{C}$ ), mass loss is estimated between $2.5 \%$ to $5 \% . \Delta \mathrm{m}_{2}$ : loss of mass around the 
interval ( 400 to $500{ }^{\circ} \mathrm{C}$ ) corresponds to the decomposition of portlandite $\mathrm{Ca}(\mathrm{OH})_{2}$ and the evaporation of water chemically linked between molecules, this loss is the same for all of the variants studied (1). $\Delta \mathrm{m}_{3}$ : very significant loss of mass, around 800 to $850^{\circ} \mathrm{C}$, reflects the decomposition of the calcite $\mathrm{CaCO}_{3}$ contained in the grains of sand, in the carbonate portlandite and also in the cement, the loss of mass is estimated between $30 \%$ to $35 \%$.

\subsection{Scanning electron microscope (SEM) analysis}

The scanning electron microscope (SEM) used for this work is a Hitachi S-4700 with field effect. Since the detector allows working at low voltage and high voltage, its high resolution is a few nanometers. The observations of the various constituent phases of the mortar samples were made at the materials characterization center. The metalized samples are observed with SEM in "secondary electron" mode to determine the textural characteristics and carry out a few point identifications. The mortar microstructure can be identified using a scanning electron microscope from fractures or polished surfaces. Figure 15 represents the photos of scanning electron microscope (SEM) obtained.

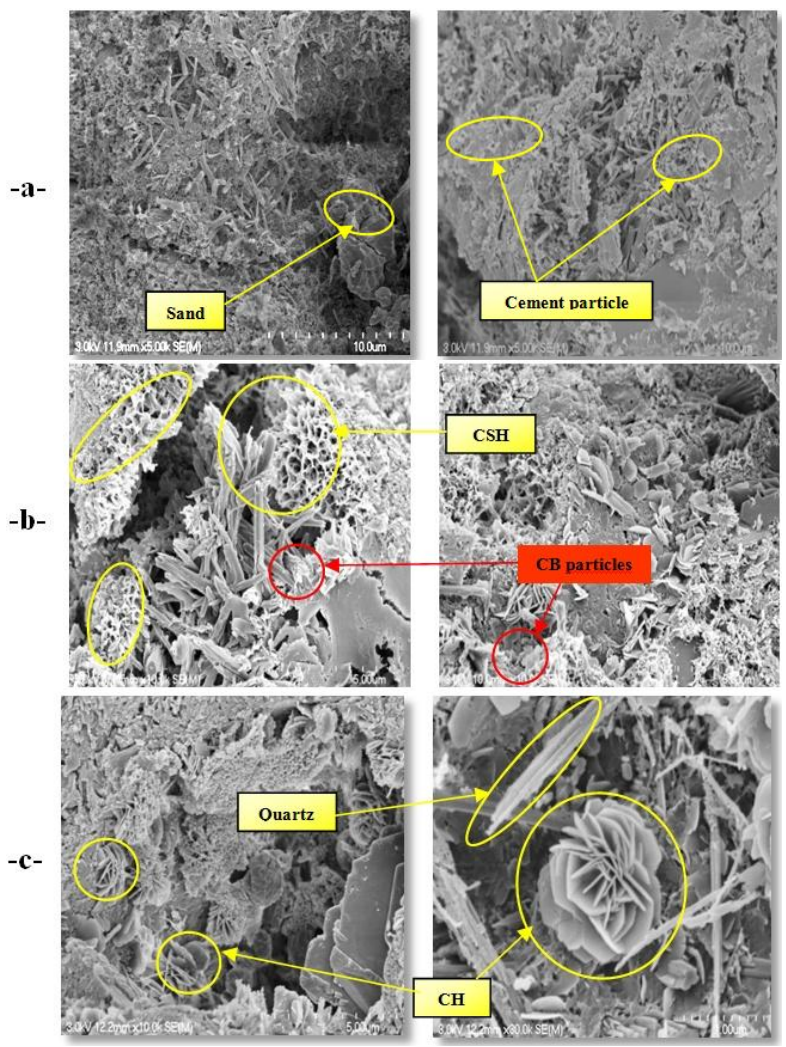

Figure 15. SEM views of some OPC (a) and mortar substituted with calcinated bentonite $(b, c)$

We note on the micrographs by scanning electron microscope (SEM) of the control mortar and with substitution several cases: quartz, $\mathrm{CSH}, \mathrm{CH}$, Portlandite and mainly anhydrous cement grain. The figures show respectively the presence of portlandite in a vacuole of $10 \mu \mathrm{m}$ in diameter and quartz crystals in the case where a mortar control. From the photos we notice: the fluffy appearance of the cement paste corresponding to the texture of $\mathrm{C}-\mathrm{S}-\mathrm{H}$ and on the same scale we also deduce platelets of $\mathrm{CH}$. also shows that quartz crystals result from gypsum added to the clinker ( 3 to $5 \%$ by weight) is not in sufficient content to transform all the aluminates into ettringite. Secondly, a monosulfoaluminate appears which crystallizes into hexagonal platelets. The reaction is given by:

$$
\begin{aligned}
& \mathrm{C}_{3} \mathrm{~A} 3\left(\mathrm{CaSO}_{4} 2 \mathrm{H}_{2} \mathrm{O}\right) \mathrm{H} 32+2 \mathrm{C}_{3} \mathrm{~A}+4 \mathrm{H} \rightarrow \\
& \mathrm{C}_{3} \mathrm{~A}\left(\mathrm{CaSO}_{4} 2 \mathrm{H}_{2} \mathrm{O}\right) \mathrm{H} 12
\end{aligned}
$$

The hydrated aluminates thus obtained occupy 15 to $20 \%$ of the volume of the completely hydrated cement paste. The cement hydration reaction combines the hydration reactions of the main components of the clinker and possibly those of its secondary components. However, the reactions are more complex due to the chemical and thermal interactions which occur during the hydration process and due to the impurities present in the solid solution and the additions which greatly influence the hydration of each phase.

\section{CONCLUSION}

Our work aims to define the physico-chemical properties as well as the structural (TGA-DSC) and microstructural (SEM) characteristics, by replacing a part of cement with different contents of calcined clays. An experimental study has been developed to analyze the physico-chemical characteristics. The following conclusions should be drawn:

- The substitution rates of calcined bentonite in CEM I cement (OPC) positively affect water absorption. This positive condition can be attributed to the filler effect due to its very large specific surface area (SSB) and the formation of C-S-H gels.

- The incorporation and substitution of a part of cement by clay tend to increase the dosage demand for superplasticizer.

- Following the results, a calcined bentonite content of $14 \%$ is chosen as the optimal dosage to produce a resistant mortar.

- The XRD patterns of "as is" and "heated" bentonite possessed both crystalline and amorphous phases.

- The addition of clays in the mortar in amounts up to $12 \%$ of calcined bentonite has greatly improved the quality of impermeability standpoint mortars.

- The estimation of the pozzolanic reaction by the physic-chemical method showed that the substitution of a part of cement by calcined bentonite showed that the loss of mass decreased and the formation of $\mathrm{C}-\mathrm{S}-\mathrm{H}$ when the replacement rate increases.

- Very significant loss of mass, around 800 to $850^{\circ}$ $\mathrm{C}$, reflects the decomposition of the calcite $\mathrm{CaCO} 3$ contained in the grains of sand, in the carbonate portlandite and also in the cement, the loss of mass is estimated between $30 \%$ to $35 \%$.

- From scanning electron microscope (SEM) micrographs of the substituted mortar, the hydration reaction of cement combines the hydration reactions of the main components of the clinker and possibly those of its secondary components. However, the reactions are more complex due to the chemical and thermal interactions that occur during the hydration process 


\section{References}

Heede, P.V.d. and N.D. Belie, 2012. Environmental impact and life cycle assessment (LCA) of traditional and green concretes: literature review and theoretical calculations Cem. Concr. Comp, 34(431). https://doi.org/10.1016/j.cemconcomp.2012.01.004.

Monteiro P, 2012. Portland Cement. Powerpoint Presentation. University of California - Berkley, p. 1-38.

Boukhelkhal, A., et al., 2016. Effects of marble powder as a partial replacement of cement on some engineering properties of selfcompacting concrete. J. Adhes. Sci. Technol,30(22):p.24052419. https://doi.org/10.1080/01694243.2016.1184402.

Schneider, M., et al., 2011. Sustainable cement productionpresent and future. Cem. Concr. Res, 41(642). https://doi.org/10.1016/j.cemconres.2011.03.019.

Kosmatka, S.H. and M.L.,2011. Wilson, Design and Control of Concrete Mixtures. Port. Cem. Assoc., Skokie, III.

Penson Curtis Robert, 2019. Calcined calcium bentonite clay as a partial replacement of Portland cement in mortar. University of British Columbia, https://dx.doi.org/10.14288/1.0376847.

Rackel S N, 2011. Approche performantielle des bétons avec Métakaolins obtenus par calcination flash. Thèse de doctorat, Université de Toulouse.

Pelisser, F., A. Vieira, and A M Bernardin,2018. Efficient selfcompacting concrete with low cement consumption. J. Clean. Prod, 175: p. 324-332. http://doi: 10.1590/s167886212020000200387.

Taher A, 2003. Effect of Heat on The Behaviour of Montmorillonite Clay In The Presence of Lime. Role of Cement Science In Sustainable Development, Dundee:Thomas Telford.: p. 311-318. doi: 10.1680/rocsisd.32460.0031.

R Sharma and R A Khan,2018. Influence of copper slag and metakaolin on the durability of self-compacting concrete. J. Clean. Prod, (171): p. 1171-1186. https://doi.org/10.1016/j.jclepro.2017.10.029.

Memon, S.A., et al., 2011. Utilization of Pakistani bentonite as partial replacement of cement in concrete. Construction and Building Materials, 30(0): p. 237-242. http://doi:10.1016/j.conbuildmat.2011.11.021.

Rajczyk, J. and B. Langier, 2012. Concrete Composite Properties with Modified Sodium Bentonite in Material Application Engineering. Advanced Materials Research, Trans Tech Pub, p. 154-157;

https://doi.org/10.4028/www.scientific.net/AMR.583.154.

Mirza, J., et al., 2009. Pakistani bentonite in mortars and concrete as low cost construction material. Applied Clay $\begin{array}{llll}\text { Science, } & 45(4): & \text { p. } & 220-226 .\end{array}$ http://doi:10.1016/j.clay.2009.06.011.

Ahmad, S., et al., 2011. Effect of Pakistani bentonite on properties of mortar and concrete. Clay Minerals, 2011. 46(1): p. 85-92. http:// doi: 10.1180/claymin.2011.046.1.85.

Khushnood, R.A., et al., 2014. Experimental Investigation on Use of Wheat Straw Ash and Bentonite in Self-Compacting Cementitious System. Advances in Materials Science and Engineering, 2014: p. 11. https://doi.org/10.1155/2014/832508.
Taylor-Lange, S.C., et al., 2015. Calcined kaolinite-bentonite clay blends as supplementary cementitious materials. Applied Clay Science, 108: $\quad$ p. 84-93. http://dx.doi.org/10.1016/j.clay.2015.01.025.

Zine El-Abidine, L. and al, 2020. Experimental investigation on effects of calcined bentonite on fresh,strength and durability properties of sustainable self-compactingconcrete. Construction and Building Materials (230): p. 1-11. https://doi.org/10.1016/j.conbuildmat.2019.117062.

NF EN 196-1,2006. Méthodes d'essais des ciments - Partie 1 : détermination des résistances mécaniques.

ASTM C150 M, 2011. Standard Specification for Portland Cement” ASTM International, West Conshohocken, PA.

NF EN 197-1, 2012. ciment - Partie 1: composition, spécifications et critères de conformité des ciments courants.

NF EN 933-1, 2012. Essais pour déterminer les caractéristiques géométriques des granulats - Partie 1 : détermination de la granularité - Analyse granulométrique par tamisage.

NF P15-403, 1963. Liants hydrauliques. Technique des essais. Sable normal et mortier normal.

NF P 15-467, 1985. Liants hydrauliques - Méthode pratique instrumentale d'analyse des ciments par spectrométrie de fluorescence des rayons $\mathrm{X}$.

Hluchy M M, 1999. The value of teaching X-ray techniques and clay mineralogy to undergraduates. journal .Geoscience education, (47): p. 236-240. https://doi.org/10.5408/1089-999547.3.236.

Brady, et al., 1995. New uses for powder X-ray diffractio expriments in the undergraduate curriculum. Journal .Geol education, 43(5): p. 466-470.

Hollecher and Kurt (2012), a long-term mineralogy practical exam, in:brady, J Mogk,D and Perkins (eds) Teaching Mineralogy, Mineragical Society of America p. 43-46.

Perkins, Dester, and Sorensen (2021), Mineral Synthesis and Xray Diffraction Experiments in: Brady, J Mogk, D. and Perkins (eds.) Teaching Mineralogy, Mineragical. Society of America p. 81-90.

NF P 18-582 (2017), Analyse thermogravimétrique (ATD_TG)

Garg, N. and J. Skibsted, 2014. Hermal activation of a pure montmorillonite clay and its reactivity in cementations systems. J. Phys. Chem, (118): p. 11464-11477. http://doi: $10.1021 /$ jp502529d.

Abali, Y., S.U. Bayca, and S. Targan, 2006. Evaluation of blends tincal waste, volcanic tuff, bentonite and fly ash for use as a cement admixture. Journal of Hazardous Materials, 131(1-3): p. 126-130. http://doi:10.1016/j.jhazmat.2005.09.031.

Sonebi, M., et al., 2012. Characterisation of the performance of sustainable groucontaining bentonite for geotechnical applications, in The international conference on Sustainable Built Environment for Now and the Future, Hanoi, Vietnam p. 1-10.

ASTM C618 a, 2008. Standard Specification for Coal Fly Ash and Raw or Calcined Natural Pozzolan for Use in Concrete. ASTM International. 
Khelifa Mohammed Rissel, 2009. Effet de l'attaque sulfatique externe sur la durabilité des bétons autoplaçants, 2009, Université d'Orléans.

Hu, Y., Diao, L., Lai, Z.Y., He, Yan, T., He, X., Wu, J., Lu, Z.Y., Lv, S.Z. (2019). Effects of bentonite on pore structure and permeability of cement mortar. Construction and building materials, vol. 224, 276-283, DOI: 10.1016/j.conbuldmat.2019.08.037.

Man, X.Y., Haque, M.A., Chen, B (2019). Engineering propreties and microstructure analyses of magnesium phosphate cement mortar containing bentonite clay. Construction and building materials, Vol. 227, DOI: 10.1016/j.conbuldmat.2019.08.037.

Noureddine, M., Khaled, B., Abdelbaki, B., (2018). Study of the impact of bentonite on the physico-mechanical and flow properties of cement grout. Cogent engineering, 5: 1446252, DOI.org/10.1080/23311916.2018.1446252. 